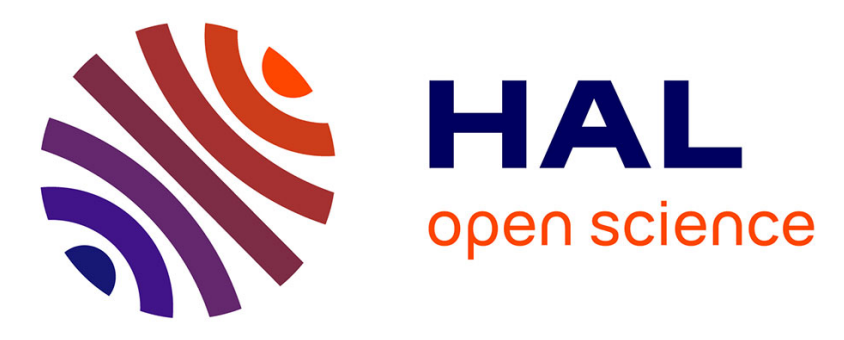

\title{
Deep infiltration through a sandy alluvial fan in semiarid Niger inferred from electrical conductivity survey, vadose zone chemistry and hydrological modelling
}

Sylvain Massuel, Guillaume Favreau, Marc Descloitres, Yann Le Troquer, Yves Albouy, Bernard Cappelaere

\section{To cite this version:}

Sylvain Massuel, Guillaume Favreau, Marc Descloitres, Yann Le Troquer, Yves Albouy, et al.. Deep infiltration through a sandy alluvial fan in semiarid Niger inferred from electrical conductivity survey, vadose zone chemistry and hydrological modelling. CATENA, 2006, 67 (2), pp.105-118. 10.1016/j.catena.2006.02.009 . ird-00165668

\section{HAL Id: ird-00165668 https://hal.ird.fr/ird-00165668}

Submitted on 27 Jul 2007

HAL is a multi-disciplinary open access archive for the deposit and dissemination of scientific research documents, whether they are published or not. The documents may come from teaching and research institutions in France or abroad, or from public or private research centers.
L'archive ouverte pluridisciplinaire HAL, est destinée au dépôt et à la diffusion de documents scientifiques de niveau recherche, publiés ou non, émanant des établissements d'enseignement et de recherche français ou étrangers, des laboratoires publics ou privés. 
Deep infiltration through a sandy alluvial fan in semiarid Niger inferred from electrical conductivity survey, vadose zone chemistry and hydrological modelling

Sylvain Massuel, Guillaume Favreau, Marc Descloitres, Yann Le Troquer, Yves Albouy, Bernard Cappelaere

\section{Catena}

www.elsevier.com/locate/catena

Volume 67, Number 2, October 2006

pp. $105-118$

also available online at www.sciencedirect.com 
Deep infiltration through a sandy alluvial fan in semiarid Niger inferred from electrical conductivity survey,
vadose zone chemistry and hydrological modelling

Sylvain MASSUEL ${ }^{\mathrm{a},{ }^{*},}$, Guillaume FAVREAU ${ }^{\mathrm{a}}$, Marc DESCLOITRES ${ }^{\mathrm{b}}$, Yann LE TROQUER ${ }^{c}$, Yves ALBOUY ${ }^{c}$, Bernard CAPPELAERE ${ }^{a}$

${ }^{a}$ IRD, UMR HydroSciences (IRD / CNRS / UMI / UMII), MSE, B.P. 64501, 34394 Montpellier Cedex 5, France.

* to whom the correspondence should be addressed.

Fax: +33 (0)467144774

E-mail: s.massuel@CGIAR.ORG

${ }^{b} I R D$, UR Geovast, Bangalore, India.

${ }^{c}$ IRD, UR Geovast, 92143 Bondy cedex, France 


\section{Abstract}

In semiarid southwestern Niger, most of the groundwater recharge is indirect and occurs through endoreic pools. Elsewhere in the landscape, there is no evidence of deep infiltration, with the possible exception for gullies and alluvial fans on sandy slopes. In order to verify this hypothesis, a detailed geophysical and geochemical survey was conducted on a large, representative mid-slope fan (6 ha). At this site, distributed hydrological modelling conducted over the encompassing endoreic catchment (190 ha) showed high losses of runoff water by infiltration. Electromagnetic mapping and 2-D electrical imaging survey were used to investigate the $35 \mathrm{~m}$ deep vadose zone; in addition, 8 boreholes were drilled following the geophysical survey to constrain the interpretation. Variations in apparent electrical conductivity measured in boreholes appear to be mainly linked with changes in the soil solution mineralization. An extrapolation throughout the area shows that apparent electrical conductivity of the ground is systematically lower below channels; this suggests localised leaching through the unsaturated zone. A physically-based, 2-D distributed hydrological model was used to estimate the amount of surface water loss by infiltration for the 1992-2002 period. Depending on year, infiltrated volumes range from 1000 to $24000 \mathrm{~m}^{3}$. This represents between 5 and $16 \%$ of the runoff that reaches the final outlet of the basin, an endoreic valley bottom pond where recharge to the aquifer has been shown to occur. Because leaching of the vadose zone is observed down to a depth of $10 \mathrm{~m}$ below channels, episodic groundwater recharge through sandy mid-slope fans is highly probable during rainy years.

keywords Niger; Semiarid area; Infiltration; Local recharge; Alluvial fan; Geophysical survey; Unsaturated zone chemistry 


\section{Introduction}

In southwestern Niger, since the early 1990s, hydrodynamics and geochemical methods have been applied at a regional scale $\left(4000 \mathrm{~km}^{2}\right)$ to estimate natural groundwater recharge to the unconfined aquifer (Leduc et al., 1997; Favreau et al., 2002). In arid and semiarid Niger, studying groundwater recharge is of paramount importance for sustainable development, as most of the population depends upon this single permanent water resource for its own consumption. In this environment, most of the groundwater recharge is indirect and occurs through endoreic ponds, natural outlets of a mosaic of catchments of the order of a few square kilometres (Desconnets et al., 1997; Martin-Rosales and Leduc, 2003). Elsewhere in the landscape, infiltration deeper than $5 \mathrm{~m}$ below the soil surface, estimated by neutron probe and soil moisture surveys, has not been evidenced and has only been suggested as possible under specific locations such as narrow banded vegetation on the plateaux (Galle et al., 1999) and gullies in the sandy hillslopes (Peugeot, 1995; Peugeot et al., 1997; Esteves and Lapetite, 2003). Surprisingly, whereas rainfall decreased by about $20 \%$ since the 1950-60s, hydrodynamics investigations have revealed a continuous increase in groundwater reserves of about $4 \mathrm{~m}$ for the last four decades, a phenomenon explained by the intense land clearing that has induced crusting of the top $\mathrm{cm}$ of the soil; as elsewhere in the Sahel, soil crusting has enhanced Hortonian runoff, thus increasing both the number of endoreic ponds and the amount of surface water reaching the ponds (Leduc et al., 2001; Seguis et al., 2004). Increased runoff may also have enhanced deep infiltration at some runoff collecting sites other than ponds, but those have not been identified yet.

The main objective of this study is to investigate the possibility of deep infiltration (i.e. typically deeper than $5 \mathrm{~m}$ ) below the drainage network on the sandy slopes of this area. In semiarid areas, deep infiltration producing groundwater recharge is very localized in time and space and difficult to estimate; combining various methods is often the key to obtain reliable results (Scanlon et al., 1999a; Simmers, 2003). Our approach is based upon a combination of sub-surface and borehole geophysics, vadose zone chemistry and physically-based hydrological modelling. 
Subsurface geophysics used in this study is aimed at mapping differences in electrical conductivity that could be linked to variations in water content and/or conductivity of the pore water and/or soil texture within the unsaturated zone, both laterally and vertically. Such differences are expected in the study site (Fig. 1), a densely braided sandy channel area where infiltration is supposed to occur (Cappelaere et al., 2003). When correlated with unsaturated zone profiles of geochemical tracers, electrical conductivity mapping can provide reliable extrapolation of punctual estimate of recharge; subsurface geophysics can also help to spatially better constrain hydrological models of surface/subsurface flows. Previous investigations in semiarid areas have shown that geophysical methods based on electrical conductivity measurements are often well suited to delineate electrical properties of the subsurface. Among the methods measuring electrical conductivity at various depths, the more suitable are: (i) Direct Current (DC) resistivity mapping or sounding (e.g. Descloitres et al., 2003) and 2D-DC electrical imaging when the ground can not be approximated by a 1D model (e.g. Beauvais et al., 2004), (ii) Frequency-Domain Electromagnetics (FEM) mapping (e.g. Cook et al., 1989; Scanlon et al., 1999a; Scanlon et al., 1999b), while (iii) Time-Domain electromagnetic method (TDEM) is also considered as a suitable tool in some situations as deep aquifers and mineralised waters (e.g. Guérin et al., 2001). Within the scope of this study, the main objective was to map the heterogeneities in electrical conductivity down to depths exceeding $30 \mathrm{~m}$ below a large mid-slope alluvial fan. FEM mapping was carried out at the site-scale; in addition, a 2D DC electrical imaging was performed on a representative cross-section of the fan.

Vadose zone geochemistry is a widely used approach in semiarid areas to infer mean groundwater recharge rates and estimates of its temporal changes (e.g. Edmunds et al., 1991). This approach has also been frequently used as a supplementary tool in regional groundwater balance studies (e.g. Wood and Sanford, 1995). Because it provides only point-scale estimates, more representative results are obtained when it is used with complementary approaches, including sub-surface resistivity mapping (Cook et al., 1989; Scanlon et al., 1999a; Scanlon et al., 1999b). In southwestern Niger, data on the deep unsaturated zone are limited. In the study area, previous data were limited to the first upper metre (e.g. Wezel et al., 2000), and 
for a single study, to a depth of up to few metres (Nagumo, 1992). However, tracking deep infiltration requires getting information down to several tens of metres (ideally, to the water table). In this study, vadose zone chemistry is used, along with other parameters (water potential, texture, water content), both to interpret the measured differences in electrical conductivity and to better estimate the solute and water balance in the studied area.

In semiarid regions, the difficulty in obtaining good quality data records of ephemeral and episodic floods is widely recognized (e.g. Lange et al., 1999). Physically based, spatially distributed hydrological modelling is a way to overcome these difficulties, and can be used to generate data for ungauged parts of a catchment. This approach was chosen for the catchment that includes the studied mid-slope alluvial fan (Fig. 1; Peugeot et al., 2003; Cappelaere et al., 2003). For the present study, the water balance of the fan was computed at the rainfall-event scale through the 1992-2002 decade, thus providing consistent values of annual surface water loss by infiltration. From this set of data, a hydrological functioning of the deep unsaturated zone under sandy slopes is proposed.

\section{Study site}

The study site is located in the Sahelian southwestern Niger, at $60 \mathrm{~km}$ east of Niamey (Fig. 1). The climate is semiarid, with a mean annual temperature of $29^{\circ} \mathrm{C}$, a mean potential evapotranspiration near $2500 \mathrm{~mm} . \mathrm{yr}^{-1}$ and a yearly mean precipitation of $567 \mathrm{~mm}$ (Niamey, 1908-2003; Niamey Airport, pers. com.); these values are considered to be representative for the study site. The rainy season from June to September ( $90 \%$ of the annual rainfall) consists in intense rainfall events of convective origin. These short duration events produce Hortonian runoff that rapidly (within 1-3 hours) concentrates in temporary ponds, natural outlets of endoreic catchments of a few square kilometres. In this environment, all hydrological data indicate that most of the unconfined aquifer recharge is indirect and occurs by deep infiltration below the ponds (Desconnets et al., 1997; Leduc et al., 1997; MartinRosales and Leduc, 2003). The geological context is sedimentary and shallow 
formations belong to the Continental terminal (Tertiary) made up of loosely cemented clays, silts and sands of continental origin; this formation outcrops over a surface area of $150000 \mathrm{~km}^{2}$ in southwest Niger. Dating from drier periods of the Quaternary, aeolian sand deposits occur in some places and can reach a few metres in thickness. The water table elevation exhibits a classical pattern for semiarid areas: a continuous, smooth surface (hydraulic gradients $<1 \%$ ), with transient potentiometric fluctuations of up to few metres below temporary ponds during the rainy season (Leduc et al., 1997; Favreau et al., 2002). Depending on the topography, the depth to the water table varies between $75 \mathrm{~m}$ below the lateritic plateaux to less than $10 \mathrm{~m}$ below the dry valleys. The natural vegetation of the region is a wooded savannah but under increasing clearing much of the area is now a patchwork of fallow and millet fields.

The Wankama catchment (Fig. 1) has been intensively studied since 1992; details about the hydrological survey and data analysis are available elsewhere (Desconnets et al., 1997; Peugeot et al., 2003). To summarize, the catchment area is of 190 ha, with a mean slope gradient of $1.5 \%$ from west to east. At the lower end, the endoreic, elongated temporary pond acts as the natural outlet of water runoff of the basin; the gully reported in Fig. 1 represents its main tributary. According to runoff simulations for the 1992-2002 period, surface water reaching the pond varies between 23000 and $149000 \mathrm{~m}^{3} . \mathrm{yr}^{-1}$ (Table 1). Most of this water (about 90\%) infiltrates and creates a temporary mound below the pond. At mid-slope a large sandy alluvial fan ("spreading zone") acts as a natural collector of most of the surface runoff from the upstream basin (Cappelaere et al., 2003). Such large alluvial fans are a common feature in the landscape (D'Herbes and Valentin, 1997). Hillslope soils of the catchment are mainly sandy, weakly structured and can be classified, according to Soil Taxonomy, as a sandy siliceous isohyperthermic psammentic Haplustalf (Bielders et al., 2000). Organic carbon content is less than $0.5 \%$, with fine particle content typically within the range of 5-20\% (Nagumo, 1992; this study).

Within the catchment, this study focused on the alluvial fan of about 6 ha (3\% of the catchment area) occurring at mid-slope; this fan represents the main outlet of the upper part of the drainage basin (Fig. 1). Its main characteristics are as follows: mean slope of $1.6 \%$ (close to the one of $1.5 \%$ for the whole catchment); water table 
depth between 32 to $41 \mathrm{~m}$; land surface occupied by shrub fallow (mainly Guiera senegalensis), millet fields and sandy channels (17\% of the area in 2002). Whereas the main gully is narrow and reaches few metres in depth in the upper part of the catchment, the braided channels are typically large and shallow $(<0.5 \mathrm{~m})$ within the alluvial fan. Consequently, this results in possible changes of the channel patterns after exceptionally high flooding years.

\section{Methods}

\subsection{Electrical conductivity}

Ground electrical conductivity $\left(E C_{g}\right)$ is a complex function of the soil characteristics (mineralogy, texture, and structure) and of its water and solute contents. The well-known Archie's law (Archie, 1942) originally expressed for saturated formations can be transformed for the unsaturated zone as follows (Keller, 1988):

$$
\mathrm{EC}_{g}=\frac{1}{\mathrm{a}} \cdot \mathrm{EC}_{\mathrm{w}} \cdot \mathrm{S}_{\mathrm{w}}^{\mathrm{n}} \cdot \phi^{\mathrm{m}}
$$

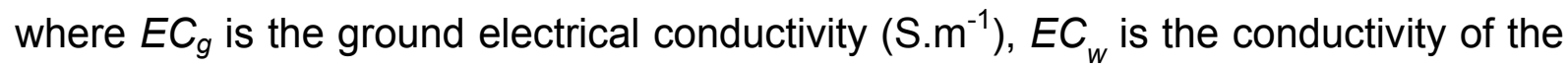
pore water $\left(\mathrm{S} . \mathrm{m}^{-1}\right), \Phi$ is the porosity (dimensionless), $S_{w}$ is the pore space saturation (dimensionless, $\mathrm{L}^{3} / \mathrm{L}^{3}$ ), $a$ is the saturation coefficient (dimensionless), $m$ is the cementation factor (dimensionless), and $n$ the saturation exponent. For the sandy formation, Keller (1988) proposes the values of $0.88,1.40$ and 2 for $a, m$ and $n$ respectively. This empirical law is valid for sandy formations; when present, clayey particles could play a role in increasing the value of the ground electrical conductivity, because of their possible high cation exchange capacity (CEC). As a consequence, the ground electrical conductivity $E C_{g}$ can vary over a wide scale of values, ranging from more than $1000 \mu S . \mathrm{cm}^{-1}$ for clayey saturated material to less than 10 or even $1 \mu \mathrm{S} . \mathrm{cm}^{-1}$ for dry sand. The $E C_{w}$ and $S_{w}$ variables are difficult to obtain in the field. In this study, these parameters are estimated by surrogates obtained in the laboratory, 
respectively the experimental conductivity $E C_{\text {we }}$ produced with the usual lixiviation protocol, and the gravimetric water content $\theta_{w}$ (moisture weight/total weight). From equation (1) it is shown that the ground electrical conductivity $E C_{g}$ given by geophysical methods is highly dependent on the saturation, the porosity and the electrical conductivity of the water in the soil.

Electromagnetic (EM) mapping was performed using a Geonics EM-34 electromagnetic device to survey the watershed with three intercoil spacings, 10, 20 and $40 \mathrm{~m}$. The operating frequencies are respectively 6400,1600 and $400 \mathrm{~Hz}$. For practical reasons, the coils were aligned vertically (horizontal dipole mode), providing a stable reading of the ground electrical conductivity at three depths of investigation. This survey design provides a good sensitivity to the upper surface layer conductivity, and an investigation depth that can be roughly comparable to the intercoil spacing. The ratio of secondary to primary magnetic field over a uniform earth is directly proportional to the ground electrical conductivity $E C_{g}$ (Mc Neill, 1980). In the case of an electrically layered ground (1D case), the reading is given as an apparent electrical conductivity $E C_{a}$, which is a function of the respective conductivities of each layer. Two measurement campaigns were performed. In August, 2002 the entire catchment was covered using the $40 \mathrm{~m}$ intercoil spacing (Fig. 2). Then the survey was dedicated to a preliminary mapping of the fan area using the intercoil spacings 10 and 20 m, with measurement every $40 \mathrm{~m}$ (Fig.3a and b). In March, 2003, a map of the whole alluvial fan $(425 \times 400 \mathrm{~m})$ was performed using the $20 \mathrm{~m}$ intercoil spacing, with measurement every $10 \mathrm{~m}$. For each campaign, a base station was monitored every 2 hours to overcome any problem due to instrumental drift.

A 2D electrical imaging survey was conducted in March 2003 along the profile AA' (Fig. 1) using a Syscal R2 resistivity-meter with 64 electrodes (IRIS Instruments). $A$ couple of electrodes ( $A$ and $B$ ) was used for current injection and the resulting potential difference was measured with a second couple of electrodes ( $M$ and $N$ ). The basic field procedures, electrode arrays and interpretation technique are described in Loke (2000). For our survey, the electrodes were laid out every $4 \mathrm{~m}$ allowing a spacing of $252 \mathrm{~m}$, that was repeated once to perform a profile of $508 \mathrm{~m}$ (Fig. 4). Due to the very dry sandy surface, the contact resistance was decreased by 
digging $20 \mathrm{~cm}$ deep pits, filled with a salty clayey mud. The acquisition was performed combining 2 arrays, the Wenner and Dipole-Dipole, taking advantage of their different sensitivity to 2D distribution of the ground resistivity. The Wenner and Dipole-Dipole data sets have been interpreted jointly using the RES2DINV inversion software (Loke, 2000).

Electrical conductivity logging was performed in the vadose zone using an inflatable logging tool (Descloitres and Le Troquer, 2004) in each of the 8 drilled auger holes (Fig. 1); the acquisition was done using the "normal" pole-pole array. This quadripole involves two inner electrodes $A$ and $M$ and two remote surface electrodes $B$ and $N$ at $150 \mathrm{~m}$ away from the drill hole. The AM spacing was $0.25 \mathrm{~m}$. The measurements were done every $0.5 \mathrm{~m}$ down the hole. The short spacing between electrodes $A$ and $M$ allows measurements of the ground electrical conductivity $E C_{g}$ within an estimated radius of $20 \mathrm{~cm}$ around the sampling point.

\subsection{Vadose zone chemistry}

For this study, 8 boreholes of $50 \mathrm{~mm}$ of diameter were drilled without any fluid to depths between 5 to $25 \mathrm{~m}$ in August, 2002 (drill holes 1 and 2) and March, 2003 (drill holes 3 to 8 ) with a power engine drillmite auger (locations are shown in Fig. 1). At surface, soil samples were collected each $0.5 \mathrm{~m}$ and rapidly poured using plastic gloves into $335 \mathrm{~cm}^{3}$ aluminium tins to preserve samples from evaporation and contamination. For this study, gravimetric water content, water potential measurement, particle-size analyses, experimental conductivity of the pore water, major ion chemistry and $\mathrm{pH}$ were measured. Analyses were performed in Montpellier, France, within a few months of sampling. Random duplicates showed good reproducibility. On selected samples, X-ray diffractions were also performed to determine the soil mineralogy.

Gravimetric water content $\left(\theta_{w}\right)$ was measured after drying an aliquot of about $100 \mathrm{~g}$ of each sample in an oven for 24 hours at $105^{\circ} \mathrm{C}$. Water potential was estimated for some duplicate samples by the filter-paper method described in Hamblin (1981), using Whatman-42 filter paper, with an uncertainty of about $20 \%$. Solute content was obtained after elutriation of $20 \mathrm{~g}$ of dry sediments in $50 \mathrm{ml}$ of 
double-deionised water $\left(<1 \mu \mathrm{S} . \mathrm{cm}^{-1}\right)$ during $30 \mathrm{~min}$; experimental conductivity of the pore water $\left(E C_{w e}\right)$ was subsequently measured on a $0.45 \mu \mathrm{m}$ filtered aliquot with a commercial conductimeter (WTW, Tetracon). On an unfiltered aliquot, $\mathrm{pH}_{\mathrm{H}_{2} \mathrm{O}}$ and

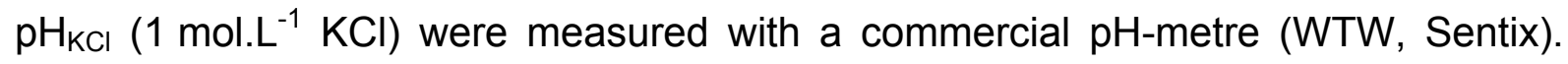
Major ions were analysed on $0.45 \mu \mathrm{m}$ filtered aliquots by capillary ion analyser (precision of about 5\%). Particle-size was analyzed by sedimentation on 25 selected samples from drill holes 1 and 2 using the pipette-method with an automatic particlesize analyser.

\subsection{Hydrological model}

The physically based, 2D-distributed hydrologic model of Cappelaere et al. (2003) was used for the present study. This model was built using the abc-rwf generic model developed by these authors from the original $r$.water.fea model of Vieux and Gaur (1994). In this model, time and space are discretized consistently and finely enough to represent the water flow dynamics of individual storm events over the whole catchment (grid resolution of $20 \mathrm{~m}$ ). Infiltration, runon/runoff production and routing functions (kinematic-wave with Green-Ampt and Manning equations) are fully coupled, and solved concurrently using finite elements in space and finite differences in time. The model was calibrated and validated for the Wankama catchment based on the rainfall events that occurred from 1992 to 2000 and reproduced the observed catchment behaviour satisfactorily (Cappelaere et al., 2003). The alluvial fan is represented in the model by a 7.6 ha area with the normal DEM slope.

\section{Results}

\subsection{Electromagnetic mapping}

Electromagnetic mapping was used to delineate relative differences in vadose zone conductivity. In Fig. 2 are presented the EM34 40 m-spacing mapping results at the catchment scale. Apparent electrical conductivity values range from 10 to 
$200 \mu \mathrm{S} . \mathrm{cm}^{-1}$ (1000 to $50 \Omega . \mathrm{m}$ respectively) and show a general increase from upslope (west) to downslope (east). This trend is explained by a decreasing thickness of the vadose zone with decreasing elevation: when going downward, the thickness of the resistive (unsaturated) ground decreased from more than $60 \mathrm{~m}$ down to less than $20 \mathrm{~m}$, thus raising the measured apparent electrical conductivity value. On the sandy fan area (Fig. 2), the values lay between 36 at the north and $83 \mu \mathrm{S} . \mathrm{cm}^{-}$ ${ }^{1}$ at the centre (between 280 and $120 \Omega$.m, respectively). The two deeper drill holes (1 and 2, Fig. 2) were installed to explain this contrast: drill hole 1 was located at a higher apparent electrical conductivity anomaly near a large channel, whereas drill hole 2 was located in a low apparent electrical conductivity spot, corresponding to a small-slope fallow plot (Fig. 2).

Results from the shallow sub-surface were obtained using shorter intercoil spacings. Fig. 3 presents the results of the EM mapping focusing on the sandy fan area, using intercoil spacings of respectively 10 (Fig. 3a) and $20 \mathrm{~m}$ (Fig. 3b, 3c). The $10 \mathrm{~m}$ spacing map shows apparent conductivities lying between 11 and $50 \mu \mathrm{S} . \mathrm{cm}^{-1}$ (from 900 to $200 \Omega$.m respectively). The distribution of the poorly conductive zones appears complex: in the centre, it could be linked with the dense channel distribution. Except for the middle part of the northern gully, large spots of higher apparent electrical conductivity occur away from the main gullies. The $20 \mathrm{~m}$ spacing map shows the same range of values, from 11 to $50 \mu \mathrm{S} . \mathrm{cm}^{-1}$ (Fig. 3b). The less conductive spots (below $17 \mu \mathrm{S} . \mathrm{cm}^{-1}$ ) are distributed at the centre and in the northeastern part of the area, and higher apparent conductivities are observed in the southern and nortwestern parts. In details, significant differences appear with the $10 \mathrm{~m}$ intercoil spacing map; this may be due to the time-lag between the two field measurements ( $\sim$ month) and to subsequent surface water infiltration (see §4.4) and/or to locally heterogeneous distribution of apparent conductivities with depth.

In March, 2003 a larger EM-34 survey of the fan (18 ha, intercoil spacing of $20 \mathrm{~m}$, north-south tracking, measurement each $10 \mathrm{~m}$ ) confirmed the observations obtained in the lower part of the fan (Figs. 3a and 3b); in particular, (i) though the measurements took place by the end of the dry season, the same range of values was observed and (ii) large spots of higher apparent electrical conductivity occurred around the fan, with, in details, a more complex zonation (Fig. 3c). 
In order to compare methods, EM-34 measurements with intercoil spacing of $20 \mathrm{~m}$ were performed simultaneously to the $2 \mathrm{D}$ electrical imaging on a single profile (AA' in Fig. 1; Fig. 4). In accordance with EM-34 mapping results, relatively lower apparent electrical conductivity was observed below the main gullies.

\section{2. $2 D$ electrical imaging}

A two dimensional (2D), $508 \mathrm{~m}$-long electrical imaging profile was performed perpendicularly to the fan area (Fig. 1). In Fig. 4 is reported the calculated ground electrical conductivity versus depth obtained by joint inversion of the Wenner and Dipole-Dipole 2D data sets. The number of iterations was limited to three because there was no significant decrease of the RMS criteria for further inversions. As the inversion has to comply with two sets of data, the corresponding RMS is relatively high $(19 \%)$. The conductivities range from 1.25 to $330 \mu \mathrm{S} . \mathrm{cm}^{-1}$ (8 000 to $30 \Omega . \mathrm{m}$, respectively). From the surface down to 2-3 $\mathrm{m}$ a resistive layer is noted, and corresponds to a dry sandy layer (March 2003, dry season); from $3 \mathrm{~m}$ to $10 \mathrm{~m}$, a conductive layer is observed. Its conductivity ranges from 60 to more than $300 \mu \mathrm{S} . \mathrm{cm}^{-1}$ in a discontinuous way, forming patches with higher conductivity separated by lower conductivity ones. Below this level, from 10 down to $35 \mathrm{~m}$ (maximum depth of investigation), the vadose zone is mostly resistive. Its conductivity mostly ranges from 1.25 to $3.3 \mu \mathrm{S} . \mathrm{cm}^{-1}$ with at some places, some more conductive patches.

\subsection{Electrical conductivity logging and vadose zone analysis}

Results of electrical conductivity logging are shown on Figs. 5a and 6a for the two deepest drill holes ( 1 and 2 ) and on Fig. 7a for the others. Each of the two drill holes 1 and 2 represents a distinct pattern of electrical conductivity change with depth. For the drill hole 1 , ground electrical conductivities are ranging from 0.8 to $15.3 \mu \mathrm{S} . \mathrm{cm}^{-1}$ (12 500 to $650 \Omega$.m). Those values are typical for an unsaturated sandy formation, with low water content. Drill holes 3, 6 and 8 display the same behaviour as the drill hole 1 with ground electrical conductivity below $20 \mu \mathrm{S} . \mathrm{cm}^{-1}(500 \Omega . \mathrm{m})$ all along the logging profile (Fig. 7a). For the drill hole 2, the range is wider, from 1.6 to 
$200 \mu \mathrm{S} . \mathrm{cm}^{-1}$ (6250 to $50 \Omega$.m). Ground electrical conductivity rapidly increases from surface to $4 \mathrm{~m}$ deep. From 5 to $10 \mathrm{~m}$ depth, the ground is more conductive, values are over $150 \mu \mathrm{S} . \mathrm{cm}^{-1}$ (below $65 \Omega . \mathrm{m}$ ) with a maximum at $8 \mathrm{~m}$ depth. These higher values typically indicate that the formation is either more clayey, contains more water or presents an increase in the water solute content. Drill holes 4, 5 and 7 have the same behaviour as the drill hole 2 with ground electrical conductivity over $100 \mu \mathrm{S} . \mathrm{cm}^{-}$ ${ }^{1}$ (below $100 \Omega$.m) when reaching $4 \mathrm{~m}$ depth (Fig. 7a).

Grain size distribution analysis shows that sedimentary formations are homogeneous between the drill holes 1 and 2 (Fig. 5d, Fig. 5e). Grounds are essentially sandy (33 to $90 \%$ ) to silty ( 3 to $28 \%$ ) with variable content of clay (3 to $41 \%)$; pebbles occur between 5 and $10 \mathrm{~m}$ in small proportion $(<10 \%)$. Two stratums are more clayey and occur at depths from 5 to $7 \mathrm{~m}$ and 10 to $12 \mathrm{~m}$ for the two drill holes. For these layers, X-ray diffractions confirm the abundance of quartz (sand) and show that clay fraction is made almost exclusively of kaolinite (goethite is also present). For the whole profiles, such a similar grain size distribution suggests that porosity could be the same for the two drill holes. Consequently, the influence of porosity $\Phi$ in Equation (1) may be similar for the two drill holes. Because kaolinite is known to have a low CEC, influence of the clay content on the apparent electrical conductivity is expected to be low.

Matric suction measurements were performed on dedicated duplicates for drill holes 1 and 2. For both profiles, deeper than $4 \mathrm{~m}$, values are high and lie between 25 to 75 bar; around 2 to $3 \mathrm{~m}$, matric suction is even higher and can reach 150 bar (Fig. 5b). At surface, it displays a rapid decrease, down to 0.05 bar at $0.1-0.7 \mathrm{~m}$ below the soil surface, followed by a steep rise in the top $\mathrm{cm}$ for drill hole 1 (Fig. $5 \mathrm{~b}$ ). Considering that sampling occurred during the rainy season (August, 2002), such a typical "S" shape can be explained by recent infiltration of rain water at shallow depth, followed by incomplete re-evaporation. However, though the two holes are located at various distances from gullies (Fig. 1), very similar water potential profiles are obtained and no noticeable difference in infiltration at the time of sampling can be inferred. This can be explained by the low amount of rainfall and runoff that occurred in 2002 (see below, §4.4), thus preventing any significant infiltration through gullies. 
Gravimetric moisture content profiles are similar in drill holes 1 and 2 (Fig. 5c). The measured $\theta_{w}$ range from 1.8 to $11.3 \%$ and are closely related to the grain size distribution (Fig. $5 d$ and 5e). Except for the top metre where $\theta_{w}$ partly represents recent infiltration (as shown by matric suction values), higher values systematically correspond to increases in clay content, and conversely lower values to decreases in clay content. Almost the same range of moisture $(0.6-10.7 \%)$ is observed for drill holes 3 to 8 that present a single pattern of increasing moisture with depth (for these holes, the lower moisture content near the soil surface can be explained by sampling during the dry season; Fig. 7c). Consequently, the influence of the saturation parameter $S_{w}$ in Equation (1) could be considered as invariant in time, space and depth $(>2 \mathrm{~m})$.

Experimental conductivity of the pore water $\left(E C_{w e}\right), \mathrm{pH}$ and ionic contents profiles are reported in Fig. 6 for drill holes 1 and 2 and in Fig. 7 for drill holes 3 to 8 respectively. For each profile, $E C_{w e}$ appears to be well correlated to ground electrical conductivity $\left(E C_{g}\right)$. As for $E C_{g}$ profiles, two distinct families of $E C_{\text {we }}$ change with depth can be distinguished, being respectively represented by drill holes 1 and 2 (Fig. 6b; Fig. 7d). For profiles of the first group (drill holes $1,3,6,8) E C_{w e}$ is rather constant with depth (except for the first top four metres) and ranges from 4 to $24 \mu \mathrm{S} . \mathrm{cm}^{-1}$; this implies a low ion content. For profiles of the second group (drill holes $2,4,7)$, the maximum $E C_{\text {we }}$ lies within the range 46 to $276 \mu \mathrm{S}_{\mathrm{cm}}{ }^{-1}$. Drill holes 5 , though related to high $E C_{g}$ values, display relatively low $E C_{w e}$ at depth and represents an exception (Fig. $7 \mathrm{~d}$ ); this may be due to local small-scale heterogeneity at the sampling location, the $E C_{g}$ value representing a larger ground volume.

$E C_{\text {we }}$ represents an integrated value of the ionic water composition. In order to determine the chemical composition of the solute content, major ion analysis $\left(\mathrm{Ca}^{2+}\right.$, $\mathrm{Mg}^{2+}, \mathrm{Na}^{+}, \mathrm{K}^{+}$, for cations, $\mathrm{SO}_{4}{ }^{2-}, \mathrm{NO}_{3}{ }^{-}$and $\mathrm{Cl}^{-}$for anions) were performed for each sample; $\mathrm{pH}-\mathrm{H}_{2} \mathrm{O}$ and $\mathrm{pH}-\mathrm{KCl}$ measurements were also performed to determine free and exchangeable $\mathrm{H}^{+}$respectively. For these two parameters, values range between 4.6 and $8.8 \mathrm{pH}$ units $\left(\mathrm{pH}-\mathrm{H}_{2} \mathrm{O}\right)$ and between 3.9 and $8.2 \mathrm{pH}$ units $(\mathrm{pH}-\mathrm{KCl})$, the positive difference ranging between 0.1 and $2.4 \mathrm{pH}$ units (Fig. 6e; Fig. 7f). Ion contents are reported graphically on Fig. $6 \mathrm{c}$ and $6 \mathrm{~d}$ for drill holes 1 and 2 and on 
Fig. $7 \mathrm{~b}$ and $7 \mathrm{e}$ for drill holes 3 to 8 . Increases in $E C_{w e}$ appear to be mainly linked with increases in $\mathrm{NO}_{3}{ }^{-}$for anions, and in $\mathrm{Ca}^{2+}$ for cations; for the highest solute contents (drill hole 4), $\mathrm{NO}_{3}{ }^{-}$and $\mathrm{Ca}^{2+}$ reach respectively 1.86 meq. $\mathrm{L}^{-1}$ (288 ppm) and 1.05 meq. $\mathrm{L}^{-1}(53 \mathrm{ppm}) . \mathrm{Mg}^{2+}$ appears to be highly correlated with $\mathrm{Ca}^{2+}$ and follows the same variations with a lower content. Some higher levels in $\mathrm{Ca}^{2+}$ and $\mathrm{Mg}^{2+}$ correspond with increases in $\mathrm{pH}$ values up to 8.6 or $8.8 \mathrm{pH}$ units (drill holes 2 and 4 respectively), thus suggesting the presence of carbonate minerals. $\mathrm{SO}_{4}{ }^{2-}$ content is always low (nearly $2 / 3$ of the analyses are below the detection threshold) and never exceed $15 \%$ of the anion content. $\mathrm{Cl}^{-}$and $\mathrm{K}^{+}$contents are always low $\left(<0.1\right.$ meq. $\mathrm{L}^{-1}$, i.e. $<9 \mathrm{ppm}$ ) and do not correlate with the bulk mineralization. In details, the vadose zone chemistry changes in chemical composition with depth, with $\mathrm{Na}^{+}$for cations and $\mathrm{Cl}^{-}$for anions being dominant for some drill holes at discrete depths (Fig. 6; Fig. 7). These results are in good agreement with previous findings in the same region of an important small scale chemical heterogeneity within the first upper metres of the ground (Nagumo, 1992).

\subsection{Hydrological modelling}

The Wankama catchment model was run on an event basis from 1992 to 2002 (Table 1). Rainfall input was recorded with rain-gauges located on the basin. The hydrological balance was computed for each cell of a $20 \mathrm{~m}$ resolution grid. According to the fully distributed model, for the whole period, all of the incoming flow was lost in the alluvial fan by infiltration. Runoff volumes $(V \Delta)$ computed at point $\Delta$ (the point of inflow for the alluvial fan, see Fig. 1) are compared with runoff volumes computed at the downslope endoreic pond $\left(V_{p}\right)$, where recharge has been shown to occur (Desconnets et al., 1997; Leduc et al., 1997). V $\Delta$ ranges between 5 to $16 \%$ (mean $13 \%$ ) of the total surface flow production computed in the pond; this represents between 1000 and $24000 \mathrm{~m}^{3}$ of surface water infiltrating through a sandy channel area estimated near 1 ha (17\% of the active part of the alluvial fan). Compared to the surface of the pond, the infiltrating fan area appears smaller (the maximum surface of the pond is near 9 ha). However, as reported in Table 1, the maximum annual $V \Delta$ entering the fan $\left(24000 \mathrm{~m}^{3}\right)$ exceeds the minimum $V_{p}$ value $\left(23000 \mathrm{~m}^{3}\right)$, for which groundwater recharge was indeed observed. Therefore, all other things being equal, 
it could be concluded that groundwater recharge may have occurred through the alluvial fan for the 1992-2002 period, at least for the highest computed yearly runoff.

Two other points inferred from the hydrological modelling approach lie (i) in the relative importance of $V \Delta v s$. $V_{p}$ depending on years and (ii) in the non-linear relationship between rainfall and runoff. According to computed values reported in Table 1 (and beyond the logical observation that high $V \Delta$ are positively correlated with high $\left.V_{p}\right)$ the relative contribution of $V \Delta$ increases with total runoff $\left(V \Delta+V_{p}\right)$; in other words, the higher the runoff, the more (in relative part) the fan area may contribute to deep infiltration. In Fig. 8a are displayed computed $V \Delta$ as a function of time for respectively a wet (1995) and dry year (2002). Fig. 8b displays total rainfall events for the same two years. Though rainfall in $1995(513 \mathrm{~mm})$ is only 1.8 times higher than in $2002(291 \mathrm{~mm})$ both the number of runoff events $(7 \mathrm{vs} .3)$ and the runoff volumes $V \Delta$ reaching the fan $\left(24000 v s .4000 \mathrm{~m}^{3}\right)$ vary in greater proportion (respectively by a factor of 2.3 and 6.0; Table 1; Fig. 8a). This further emphasizes the fact that depending on years, larger changes in runoff and eventually deep infiltration can be expected than simply inferred from changes in rainfall (Table 1).

\section{Discussion}

\subsection{Ground electrical conductivity $\left(E C_{g}\right)$ interpretation}

In the study area, direct measurements in drill holes have shown a good relationship between $E C_{g}$ and $E C_{w e}$ (Fig. $6 \mathrm{a}$ and $6 \mathrm{~b}$; Fig. $7 \mathrm{a}$ and $7 \mathrm{~d}$ ). In our case, $E C_{w e}$ is relatively high compared to the contribution expected from a solid matrix made of quartz and kaolinite with low CEC (estimated about 7.5 meq / $100 \mathrm{~g}$; Nagumo, 1992). Other matrix terms involved in $E C_{g}$ values, such as porosity $\Phi$ and granulometry do not seem to act significantly upon its observed changes (Fig. 5). Assuming that the relationships between the Archie law variables $E C_{w}$ and $S_{w}$ on one hand (Eq. 1), and their experimental surrogates $E C_{w e}$ and $\theta_{w}$ on the other hand, can be acceptably approximated by some linear or power functions (i.e., of the general 
form $y=k_{1} \cdot x^{k 2}$, with constant $k_{1}$ and $k_{2}$ for a given soil), then the transformed Archie empirical law, Eq. (1), can be reformulated as:

$$
\log E C_{g}=K+\alpha \log E C_{w e}+\beta \log \theta_{w}
$$

where $K, \alpha$ and $\beta$ are new unknown constants ( $K$ incorporates in particular the effects of Eq.(1)'s $a, m$ and $\Phi)$. These parameters in Eq. (2) can be estimated from the drill hole data by applying linear regression of Equation (2) from the drill hole data, yielding $K=0.89, \alpha=1.3$ and $\beta=0.87$ (Fig. 9). The resulting $R^{2}$ is 0.82 with a contribution by $E C_{w e}$ and $\theta_{w}$ to the expressed variance respectively of $63 \%$ and $19 \%$. This simple analytical model confirms that $E C_{w e}$ values play a prominent part on the $E C_{g}$ measurements; this observation is valid for the whole scale of $E C_{g}$ measurements, with no significant change in the determination coefficient with the $E C_{g}$ range considered.

In the study area, the quasi-exclusive $E C_{g} / E C_{w}$ relationship is in accordance with (i) the large, two order in magnitude change in $E C_{w e}$ (Fig. 6b; Fig. 7d), (ii) the kaolinic nature of the clay fraction, with consequently very low CEC and (iii) the lack of any deep infiltration during the 2002 rainy season (Fig. 5b; Fig. 8). Elsewhere in the landscape, such a simple correlation between $E C_{g}$ and $E C_{w}$ may not be observed, particularly in clayey valley bottoms (shallow water table, higher $\theta_{w}$, smaller range of $E C_{w}$ and presence of vermiculite / smectite within the clay fraction; Nagumo, 1992), and for more humid periods of measurements (possibly high and transient $\theta_{w}$ signal). Within the investigated alluvial fan area, $E C_{g}$ changes measured by sub-surface geophysics (EM-34, DC) are interpreted in terms of changes in $E C_{w}$.

EM-34 mapping at 40, 20 and $10 \mathrm{~m}$ intercoil spacing show significant changes at small scale within the studied fan area (Fig. 2 and 3). Even if the EM34 device measures only an apparent electrical conductivity $E C_{a}$ in a non uniform ground, the apparent conductivity variations measured with EM34 can be roughly related to $E C_{g}$ calculated from 2D electrical imaging inversion along the DC profile (Fig. 4). The EM34 apparent electrical conductivity variations are a representation of various vadose zone leaching intensities. Because the resolution is decreasing with depth, 
these differences are probably more related to leaching of the upper part of the investigated zone (depending on the intercoil spacing considered). Higher leaching may be observed below the densely braided channel area, whereas lower leaching is observed at distance, below fallow and millet fields (Fig. 3c). Although complex in details, the generally lower conductivity observed within the fan area expresses its hydrological functioning as a deep infiltration area. In the upper part of the fan, shifting braided channels from year to year makes difficult a detailed interpretation. In Fig. $3 \mathrm{a}$ and $3 \mathrm{~b}$, small changes in $E C_{a}$ can be noticed within the fan and could be linked with transient changes in $\theta_{w}$; however, in most parts of the fan, the general distribution of $E C_{a}$ remains constant for the survey period and expresses a stable leaching pattern.

2D DC electrical imaging (Fig. 4) highlighted the spatial extent of changes in solute contents already characterized by EM-34 and drill holes measurements. At surface, a leached sandy layer of about 2 to $3 \mathrm{~m}$ in thickness is observed throughout the transect, and could represent the mean annual depth of rain water infiltration. More in depth, a high solute content layer is mostly present between 4 to $10 \mathrm{~m}$. Different hypotheses about this solute accumulation are developed in conclusion. To the best of our knowledge, no previous evidence of a high mineralized vadose zone layer had been reported before in the region, as soil studies were restricted to the first top metres of the ground. This deep mineralized layer is interrupted at discrete places, below the main sandy channels (Fig. 4); this denotes occasional deep leaching, down to depth of at least $10 \mathrm{~m}$ (for minor channels, this relationship is less obvious, due to lower runoff and/or more recent functioning). Between this depth down to more than $25 \mathrm{~m}$ (the maximum drilling depth, at hole 1), the vadose zone displays lower solute contents, as reported in DC modelling (Fig. 4). A calculation of model uncertainty (not shown here) using RES2DINV software displays an uncertainty percentage ranging between 20 and $30 \%$ below depth of $20 \mathrm{~m}$. This uncertainty remains probably underestimated: for the drill hole 1 , the inversion displays a value of $900 \Omega . \mathrm{m}$, while the resistivity logging displays a value of

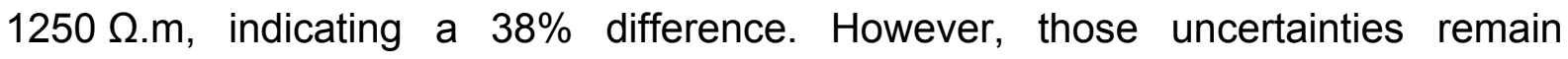
relatively low and it can be concluded that the $2 \mathrm{D}$ electrical imaging provides a reliable estimate of the bulk conductivity down to $30 \mathrm{~m}$. 


\subsection{Dynamics of deep infiltration}

One of the main challenges when dealing with groundwater in semiarid areas is to determine the main process in play for deep infiltration and eventually groundwater recharge (Simmers, 2003). The results from this study, using subsurface geophysics and vadose zone chemistry, confirm previous conclusions obtained with other methods in southwestern Niger: deep infiltration and groundwater recharge follow an indirect process, occurring only where surface runoff concentrates (Leduc et al., 1997; Desconnets et al., 1997; Favreau et al., 2002). For the studied fan area, hydrological modelling shows that runoff and deep infiltration are largely discontinuous, both at an intra-seasonal and inter-annual scale (Fig. 8); annual runoff and deep infiltration vary by about one order of magnitude for the investigated decade (Table 1). This result is consistent with previous studies (e.g., Cappelaere et al., 2003) that showed that runoff is more dependent on rainfall events distribution and magnitude than on annual rainfall amount.

Next to the study area, infiltration capacity of sandy gullies was reported in Peugeot et al. (2003) at $450 \mathrm{~mm} \cdot \mathrm{h}^{-1}$. Considering the 1 ha surface of sandy channels in the alluvial fan, the infiltration capacity could reach $4500 \mathrm{~m}^{3} \cdot \mathrm{h}^{-1}$ and therefore easily infiltrate the mean runoff event of $1600 \mathrm{~m}^{3}$ computed at point $\Delta$ for the studied decade.

A changing pattern of deep infiltration has also to be considered for the fan area, considering its long-term dynamics. Following land clearance for the last decades, a general runoff increase by a factor close to three has been computed at the catchment scale (Seguis et al., 2004). This increase in runoff has led to an upslope shifting of the $\Delta$ point (Fig. 1) due to the progradation of sandy deposits. Aerial photographs from 1950, 1992 and 1998 show that it moved westwards by about $143 \mathrm{~m}$ between 1950 and 1992, and of $79 \mathrm{~m}$ between 1992 and 1998. In Fig. 3c, the large, low conductive area, interpreted as being the most leached zone of the fan, appears to be located downslope of the densely braided gully zone, where the most active infiltration is supposed to occur. Considering the westwards movement of the fan for the last decades, the downslope location of the most 
leached zone within the study area can be interpreted as an integrated result of past leaching and deep infiltration in the downward part of the fan.

\subsection{Solute content of the vadose zone}

Chemical analyses of the vadose zone solute contents were performed in order to decipher their possible origin. A comparison with the dry and wet deposition reported for the area (Ca and $\mathrm{N}$ dominated; Drees et al., 1993; Freydier et al., 1998; Galy-Lacaux and Modi, 1998) show that the chemical composition of the most mineralized part of the vadose zone $\left(\mathrm{Ca}, \mathrm{Na}\right.$ and $\mathrm{NO}_{3}$ dominate, in various proportions) could only partly be explained by a simple rainfall infiltration - reevaporation process. On the other hand, the matrix mineralogy is mostly made of quartz and kaolinite and its incongruent dissolution could not lead to the observed vadose zone chemistry. Considering that all of the solute content stored in the vadose zone originates from atmospheric deposits (dust deposits and rainfall events), calculations based on published inputs (Drees et al., 1993; Freydier et al. 1998; GalyLacaux and Modi, 1998) show large discrepancies for the timescale required for accumulation, depending on the element considered. For instance, for the most mineralized part of drill hole 2 (the vadose zone between 5 and $11 \mathrm{~m}$, representing $75 \%$ of the solute content of the profile; Fig. 6 ), the equivalent timescale for the accumulated solute content would range from about 100 years for $\mathrm{Cl}$, up to 1200 years for $\mathrm{Na}$ (marine constituents), while of about 300 years for $\mathrm{Ca}$ (terrigenous constituent). Obviously, other sources and processes may be involved.

Within the study region, in cultivated areas and fallows with the same dominant shrub species (Guiera senegalensis) Wezel et al. (2000) described an important small scale variability of the chemical properties of the top $0.10 \mathrm{~m}$ of the soil; they showed that the chemical composition of the shrub litter seems to influence the degree of soil enrichment. In southwestern Niger, another possible source of nutrients lies in the nitrogen fixing process, either by leguminous woody plants (Acacia sp.) or by microbial crusts at the soil surface (Malam Issa et al., 2001). All of these sub-surface processes can contribute to the complex, nitrogen-rich solute content observed at depth within the unsaturated zone. A detailed study of the deep unsaturated zone, that could include isotope analysis for the biogenic constituents 
$\left({ }^{15} \mathrm{~N}-\mathrm{NO}_{3},{ }^{14} \mathrm{C} /{ }^{13} \mathrm{C}\right.$ of organic $\left.\mathrm{C}\right)$ or transient neutron probe measurements would be necessary to determine whether processes having led to this deep accumulation of solute are still active (e.g. by occasional deep infiltration followed by transpiration through deep rooting) or represent paleo-conditions dating back to the humid periods of the late Quaternary. Though deep rooting can not be ruled out, most studies have shown that Guiera senegalensis mostly extract water from the top two metres of the soil (Brunel et al., 1997; Gaze et al., 1998). The well known deep rooting Faidherbia albida is also present on the site but its today's density is too low to explain the observed high solute content within the deep unsaturated zone. Further analyses are obviously needed to better interpret the vertical distribution and solute fluxes within the deep vadose zone.

\section{Conclusion}

This local scale study of an alluvial fan in southwestern Niger combines subsurface geophysics, vadose zone analysis and hydrological modelling. Two main conclusions can be outlined:

(1) Channels in the alluvial fan act as preferential pathways for deep infiltration. By exploring the deep part of the unsaturated zone, our results confirm the occurrence of leaching down to $10 \mathrm{~m}$ below sandy channels. On the basis of hydrological modelling at the catchment scale for the decade 1992-2002, computations show that infiltration through the fan range from 1000 to $24000 \mathrm{~m}^{3}$, i.e. between 5 and $16 \%$ of surface water reaching the final outlet of the basin, an endoreic pond where recharge to the aquifer occurs annually. In the study area, deep infiltration and eventually groundwater recharge was reported to occur only through endoreic ponds, where surface runoff concentrates (Desconnets et al., 1997; MartinRosales and Leduc, 2003). This study demonstrates that deep infiltration can also occur episodically through alluvial fans on sandy slopes, thus representing additional potential sites for groundwater recharge. This result confirms previous hydrological investigation in nearby catchments that showed important surface water losses through sandy gullies for intense runoff events (Peugeot, 1995; Esteves and Lapetite, 
2003). However, our conclusion differs from a similar study in Burkina-Faso (granitic context with very clayey regolith), where surface water was reported to infiltrate not deeper than $0.80 \mathrm{~m}$ below main gullies (Descloitres et al., 2003). As outlined by Poesen et al. (2003), further studies are needed to better understand how gullies interact with hydrological processes and to determine their importance in hydrological balances.

(2) Next to recharge areas, there is a continuous layer, approximately located between 5 and $10 \mathrm{~m}$ below the soil surface, where the vadose zone displays high solute contents. This second conclusion is of much interest for the hydrological and geochemical balance of soil studies. To the best of our knowledge, the presence of a (quasi) continuous mineralized soil layer at depth between about 5 and $10 \mathrm{~m}$ below the soil surface was unknown in the area. Buerkert and Hiernaux (1998) have emphasized the complex pattern of nutrient transfers in the West African Sahelian zone. Considering the possibility for some Sahelian trees to reach several ten metres below the soil surface (e.g., Faidherbia albida; Canadell et al., 1996) there is obviously the need to take into account a deeper part of the vadose zone to balance hydrological and nutrient cycles for the Sahelian biome.

For groundwater recharge and salinity, the existence of a nitrate-rich layer at depth within the vadose zone appears as a key information to explain some observed changes with time. In southwestern Niger, some seasonal and long-term changes in groundwater chemistry have been observed near infiltrating ponds (Elbaz-Poulichet et al., 2002); these changes have been explained by seasonal recharge and leaching of the thick unsaturated zone. Our results, by identifying an important source of solute for the hydrological cycle, confirm and clarify this interpretation. In particular, some important increases in nitrate content that occurred during exceptional recharge events, at distance from any usual source of pollution (Favreau et al., 2003), could be explained by leaching of nitrate-rich layers of the vadose zone by massive infiltration of surface water.

From a methodological point of view, the absence of any relationship between chloride and bulk mineralization is another puzzling observation. In semiarid areas, the Chloride Mass Balance (CMB) method has been widely used to infer groundwater 
recharge rates, assuming that the $\mathrm{Cl}$ content closely represents the bulk salinity of the vadose zone under piston-flow recharge process (e.g., Bromley et al., 1997). However, in our study area, considering deep infiltration and groundwater recharge as a steady piston-flow process is probably not relevant. As for soil studies, a better description of the deep unsaturated zone appears as a basic prerequisite for groundwater recharge studies in semiarid areas.

This study has shown the importance of combining various methods to obtain reliable results on deep infiltration through a thick unsaturated zone. In our zone, a simple relation between soil solution conductivity (deduced from soils samples) and an apparent electrical conductivity measured by geophysics has been evidenced. As outlined in other semiarid areas (Cook et al., 1989; Scanlon et al., 1999a; Scanlon et al., 1999b) apparent electrical conductivity mapping used to delineate changes in recharge rates and process appears as a powerful method that should be used more systematically for groundwater recharge studies. When adding more sophisticated geophysical tools such as 2D electrical imaging or vadose zone electrical logging, quantification between electrical conductivity and other pertinent parameters becomes a definite advantage to better understand the processes of deep infiltration and groundwater recharge. 


\section{Acknowledgements}

This study was funded by IRD and partly by a PhD grant from the University of Montpellier II. O. Ribolzi, H. Robain, J. Touma, L. Barbiéro and L. Ruiz (IRD) are thanked for helpful discussions that improved the data interpretation. The collaboration of Sandrine Caquineau (IRD - Bondy), Monique Oï (Hydrosciences Montpellier), François Monat and Abdoulaye Koné (IRD, Niamey) and of the DRE in Niger (Direction of Hydraulic Resources, Ministry of Water Resources, Niamey) are warmly acknowledged.

\section{References}

Archie, G.E., 1942. The electrical resistivity log as an aid in determining some reservoir characteristics. Am. Inst. Min. Metallurg. Petr. Eng. Tech., paper 1422.

Beauvais, A., Ritz, M., Parisot, J.C., Bantsimba, C., Dukhan M., 2004. Combined ERT and GPR methods for investigating two-stepped lateritic weathering systems. Geoderma 119, 121-132.

Bielders, C.L., Michels, K., Rajot, J.L., 2000. On-farm evaluation of ridging and residue management practices to reduce wind erosion in Niger. Soil Sci. Soc. Am. J. 64, 1776-1785.

Bromley, J., Edmunds, W. M., Fellman, E., Brouwer, J., Gaze, S. R., Sudlow, J., Taupin, J.-D., 1997. Estimation of rainfall inputs and direct recharge to the deep unsaturated zone of southern Niger using the chloride profile method. J. Hydrol. 188-189, 139-154.

Brunel, J.P., Walker, G.R., Dighton, J.C., Monteny, B., 1997. Use of stable isotopes of water to determine the origin of water used by the vegetation and to 
partition evapotranspiration. A case study from HAPEX-Sahel. J. Hydrol. 188189, 466-481.

Buerkert, A., Hiernaux, P., 1998. Nutrients in the West African Sudano-Sahelian zone: losses, transfers and role of external inputs. Z. Pflanzenernähr. Bodenk. 161, 365-383.

Canadell, J., Jackson, R.B., Ehleringer, J.R., Mooney, H.A., Sala, O.E., Schulze, E.D., 1996. Maximum rooting depth of vegetation types at the global scale. Oecologia, 108, 583-595.

Cappelaere, B., Vieux, B. E., Peugeot, C., Maia, A., Seguis, L., 2003. Hydrologic process simulation of a semiarid, endoreic catchment in Sahelian West Niger, Africa. 2. Model calibration and uncertainty characterization. J. Hydrol. 279, 244-261.

Cook, P.G., Walker, G.R., Jolly, I.D., 1989. Spatial variability of groundwater recharge in a semiarid region. J. Hydrol. 111, 195-212.

Descloitres, M., Ribolzi, O., Le Troquer, Y., 2003. Study of infiltration in a Sahelian gully erosion area using time-lapse resistivity mapping. Catena 53, 229-253.

Descloitres, M., Le Troquer, Y., 2004. "Sonde de diagraphie électrique pour la mesure de la résistivité sur la paroi d'un forage" French Patent $n^{\circ} 2845416$, INPI, Bulletin Officiel de la Propriété Industrielle.

Desconnets, J.-C., Taupin, J.-D., Lebel, T., Leduc, C., 1997. Hydrology of the HAPEX-Sahel Central Super Site: Surface water drainage and aquifer recharge through the pool systems. J. Hydrol. 188-189, 155-178.

D'Herbes, J.-M., Valentin, C., 1997. Land surface conditions of the Niamey region: ecological and hydrological implications. J. Hydrol. 188-189, 18-42. 
Drees, L.R., Manu, A., Wilding, L.P., 1993. Characteristics of aeolian dusts in Niger, West Africa. Geoderma 59, 213-233.

Edmunds, W.M., Gaye, C.B., Fontes, J.C., 1991. A record of climatic and environmental change contained in interstitial waters from the unsaturated zone of northern Senegal. In: Isotope Techniques in Water Resources Development. IAEA Proceedings Series, Vienna, pp. 533-549.

Elbaz-Poulichet, F., Favreau, G., Leduc, C., Seidel, J.-L., 2002. Major ion chemistry of groundwaters in the Continental Terminal water table of southwestern Niger (Africa). Appl. Geochem. 17, 1343-1349.

Esteves, M., Lapetite, J.-M., 2003. A multi-scale approach of runoff generation in a Sahelian gully catchment: a case study in Niger. Catena 50, 255-271.

Favreau, G., Leduc, C., Marlin, C., Dray, M., Taupin, J.-D., Massault, M., Le Gal La Salle, C., Babic, M., 2002. Estimate of recharge of a rising water table in semiarid Niger from ${ }^{3} \mathrm{H}$ and ${ }^{14} \mathrm{C}$ modeling. Ground Water 40, 144-151.

Favreau, G., Leduc, C., Seidel, J.-L., Ousmane, S.D., Mariotti, A., 2003. Land clearance and nitrate-rich groundwater in a Sahelian aquifer, Niger. Int. Conf. Hydrology of Mediterranean and Semiarid Regions, Montpellier, France, 2003. (Servat E., Najem W., Leduc C. and Ahmed S.). IAHS Publ. n²78, 163-167.

Freydier, R., Dupré, B., Lacaux, J.P., 1998. Precipitation chemistry in intertropical Africa. Atmos. Environ. 32, 749-765.

Galle, S., Ehrmann, M., Peugeot, C., 1999. Water balance in a banded vegetation pattern. A case study of tiger bush in western Niger. Catena 37, 197-216.

Galy-Lacaux, C., Modi, A.I., 1998. Precipitation chemistry in the sahelian savanna of Niger, Africa. J. Atmos. Chem. 30, 319-343. 
Gaze, S.R., Brouwer, J., Simmonds, L.P., Bromley, J., 1998. Dry season water use patterns under Guiera senegalensis L. shrubs in a tropical savanna. J. Arid Environ. 40, 53-67.

Guérin, R., Descloitres, M., Coudrain, A., Talbi, A., Gallaire, R., 2001. Geophysical surveys for identifying saline groundwater in the semi-arid region of the central Altiplano, Bolivia. Hydrol. Process. 15, 3287-3301.

Hamblin, A. P., 1981. Filter-paper method for routine measurement of field water potential. J. Hydrol. 53, 355-360.

Keller, G.V., 1988. Rock and mineral properties. In Electromagnetic methods in Applied Geophysics, vol.1, Nabighian, M., Editor. Society of Exploration Geophysicists.

Lange, J., Leibundgut, C., Greenbaum, N., Schik, A.P., 1999. A non-calibrated rainfall-runoff model for large, arid catchments. Water Resour. Res. 35, 21612172.

Leduc, C., Schroeter, P., Bromley, J., 1997. Water table fluctuation and recharge in semi-arid climate: Some results of the HAPEX-Sahel hydrodynamic survey (Niger). J. Hydrol. 188-189, 123-138.

Leduc, C., Favreau, G., Schroeter, P., 2001. Long-term rise in a Sahelian watertable: The Continental Terminal in South-West Niger. J. Hydrol. 243, 43-54.

Loke, M.H., 2000. Electrical imaging surveys for environmental and engineering studies. Technical note of Geotomo Software, available on line at www.geoelectrical.com.

Malam Issa, O., Stal, L.J., Défarge, C., Couté, A., Trichet, J., 2001. Nitrogen fixation by microbial crusts from dessicated Sahelian soils (Niger). Soil Biol. Biochem. 33, 1425-1428. 
Martin-Rosales, W., Leduc, C., 2003. Dynamics of emptying of a temporary pond in the Sahel: The case study of Banizoumbou (southwestern Niger). C. R. Geoscience 335, 461-468.

Mc Neill, D.J., 1980. Electromagnetic terrain conductivity measurement at low induction number. Technical note TN 6 available from Geonics Limited, 1745 Meyerside Drive, Unit 8, Mississauga, Ontario, Canada.

Nagumo, F., 1992. Pedological environment and agro-ecological system of the Sudano-Sahelian zone, in Niger, West Africa. Hokkaïdo University, Japan, 101 pp.

Peugeot, C., 1995. Influence de l'encroûtement superficiel du sol sur le fonctionnement hydrologique d'un versant sahélien (Niger). Expérimentations in-situ et modélisation. Thèse de doctorat, Université Joseph Fourrier, Grenoble, 356 pp.

Peugeot, C., Esteves, M., Galle, S., Rajot, J.-L., Vandervaere, J.P., 1997. Runoff generation processes: Results and analysis of field data collected at the East Central Supersite of the HAPEX-Sahel experiment. J. Hydrol. 188-189, 179202.

Peugeot, C., Cappelaere, B., Vieux, B. E., Seguis, L., Maia, A., 2003. Hydrologic process simulation of a semiarid, endoreic catchment in Sahelian West Niger, Africa. 1. Model-aided data analysis and screening. J. Hydrol. 279, 224-243.

Poesen, J., Nachtergaele, J., Verstraeten, G., Valentin, C., 2003. Gully erosion and environmental change: importance and research needs. Catena 50, 91-133.

Scanlon, B.R., Langford, R.P., Goldsmith, R.S., 1999a. Relationship between geomorphic settings and unsaturated flow in an arid setting. Water Resour. Res. 35, 983-999. 
Scanlon, B.R., Paine, J.G., Goldsmith, R.S., 1999b. Evaluation of electromagnetic induction as a reconnaissance technique to characterize unsaturated flow in an arid setting. Ground Water 37, 296-304.

Seguis, L., Cappelaere, B., Milesi, G., Peugeot, C., Massuel, S., Favreau, G., 2004. Simulated impacts of climate change and land-clearing on runoff from a small Sahelian catchement. Hydrol. Process. 18, 3401-3413.

Simmers, I., 2003. Understanding water in a dry environment. Hydrological processes in arid and semi-arid zones. IAH Publ. 23, Balkema Publishers, the Netherlands.

Vieux, B.E. and Gaur, N., 1994. Finite-element modeling of storm water runoff using Grass GIS, Microcomput, Civil Engng 9 (4), 263-270.

Wezel A., Rajot J.L., Herbrig C., 2000. Influence of shrubs on soil characteristics and their function in Sahelian agro-ecosystems in semi-arid Niger. J. Arid Environ. 44, 383-398.

Wood, W.W., Sanford, W.E., 1995. Chemical and isotopic methods for quantifying ground-water recharge in a regional, semiarid environment. Ground Water 33, 458-468. 


\section{Table}

Table 1. Computed runoff at the point of inflow for the alluvial fan $(v \Delta)$ and at the pond $(V p)$ for the 1992-2002 period (rainfall is reported as the sum of the recorded events used for hydrological modelling).

\begin{tabular}{ccccc}
\hline Year & rainfall $(\mathrm{mm})$ & $V \Delta\left(10^{3} \mathrm{~m}^{3}\right)$ & $V p\left(10^{3} \mathrm{~m}^{3}\right)$ & $V \Delta / V p(\%)$ \\
\hline 1992 & 485 & 17 & 117 & 15 \\
1993 & 474 & 21 & 129 & 16 \\
1994 & 541 & 8 & 75 & 10 \\
1995 & 513 & 24 & 149 & 16 \\
1996 & 537 & 10 & 91 & 11 \\
1997 & 353 & 13 & 84 & 15 \\
1998 & 510 & 18 & 127 & 14 \\
1999 & 489 & 12 & 84 & 14 \\
2000 & 433 & 16 & 107 & 15 \\
2001 & 247 & 1 & 23 & 5 \\
2002 & 291 & 4 & 36 & 10 \\
Mean & 443 & 13 & 93 & 13 \\
\hline
\end{tabular}




\section{Figure captions}

Fig. 1. The Wankama watershed with zoom in on the alluvial fan area and drill holes (small inset); the thin black lines refer to the watershed Digital Elevation Model and the white network to the main gullies recorded by GPS survey in March, 2003. Inset: $A A^{\prime}$ : location of the $2 \mathrm{D}$ electrical profile (cf. Fig. 4). Numbers refer to the drill hole locations and $\Delta$ indicate the inlet of the alluvial fan where hydrological runoff estimations were computed. Aerial photographs of November, 1992 (IGNN, Niamey, Niger).

Fig. 2. EM-34 mapping at the catchment scale, intercoil spacing $40 \mathrm{~m}$ (August, 2002); measurement locations are indicated by black dots. The white network refers to the main gullies. Inset: zoom in on the apparent electrical conductivity changes at the fan scale; drill holes 1 and 2 are located on high and low conductivity anomalies, respectively.

Fig. 3. EM-34 mapping in the lower part of the fan area, $W$ to $E$ direction, intercoil spacing $10 \mathrm{~m}$ (a) and $20 \mathrm{~m}$ (b), August 2002. c): EM-34 mapping, intercoil spacing $20 \mathrm{~m}, \mathrm{~N}$ to $\mathrm{S}$ direction, March, 2003. Measurement locations are indicated by black dots. The white network refers to the main gullies. Background: microlight aircraft photograph of the fan area, August, 1998 (J.L. Rajot, IRD, Niamey, Niger).

Fig. 4. Joint analysis of Wenner $\alpha$ and $\beta$ profiles (mutual inversion) by Res2Dinv; unit electrode spacing $4 \mathrm{~m}$, iteration 3 , RMS error $19.1 \%$. A higher conductivity layer is displayed (blue colours) between 5 and $10 \mathrm{~m}$ depth; below most sandy channels this conductive layer is interrupted. Upper part of the figure: apparent electrical conductivity measured by EM-34 survey (intercoil spacing 20 m, measurement each $4 \mathrm{~m})$.

Fig. 5. Physical parameters measured in drill holes 1 and 2; a) ground electrical conductivity $E C_{g}$, b) matric suction, c) water content and d), e) grain size distribution for drill holes 1 and 2, respectively. The soil surface is respectively at 226.84 and $227.05 \mathrm{~m}$ a.m.s.l for drill holes 1 and 2 . 
Fig. 6. Chemical parameters measured in drill holes 1 and 2; a) ground electrical conductivity (reported from Figure 5), b) experimental conductivity of the pore water, c) anions, d) cations; e) $\mathrm{pH}$ and $\mathrm{pH}-\mathrm{KCl}$.

Fig. 7. Physical and chemical parameters measured in drill holes 3 to 8 . a) ground electrical conductivity $E C g$; b) anions; c) water content; d) experimental conductivity of the pore water; e) cations; f) $\mathrm{pH}$. Because both $\mathrm{Ca}$ vs. $\mathrm{Mg}$, and $\mathrm{pH}-\mathrm{H}_{2} \mathrm{O}$ vs. $\mathrm{pH}-\mathrm{KCl}$ appeared to be well correlated $\left(r^{2}\right.$ of 0.98 and 0.87 , respectively), $\mathrm{Ca}$ and $\mathrm{pH}-\mathrm{H}_{2} \mathrm{O}$ were chosen to represent their changes with depth for drill holes 3 to 8 .

Fig. 8. a) Runoff volumes computed by hydrological modelling at the point of inflow for the alluvial fan in 1995 (wet year) and 2002 (dry year). b) Measured event rainfall for these two years; vertical arrows ( 1 to 5 ) indicate dates of measurements for 2002: 1: EM-34 with $40 \mathrm{~m}$ intercoil spacing mapping, 2: EM-34 with $10 \mathrm{~m}$ intercoil spacing mapping, 3: drilling of hole 1, 4: drilling of hole 2, 5: EM-34 with $20 \mathrm{~m}$ intercoil spacing mapping.

Fig. 9. $E C_{g}$ computed as a function of $E C_{g}$ measured for the 127 measurements of the 8 drill holes with $E C_{g}=10^{K} . E C_{w e}{ }^{\alpha} \cdot \theta_{w}{ }^{\beta}$ and $K=0.89, \alpha=1.3$ and $\beta=0.87$ (the measured $E C_{g}$ are reported as a function of depth in Figs. 5a and 7a; for drill holes 1 and 2, the first two metres of measurements were excluded from the data set, the $E C_{g}$ being impossible to be correctly measured due to broadening of the upper part of the hole during the drilling). 


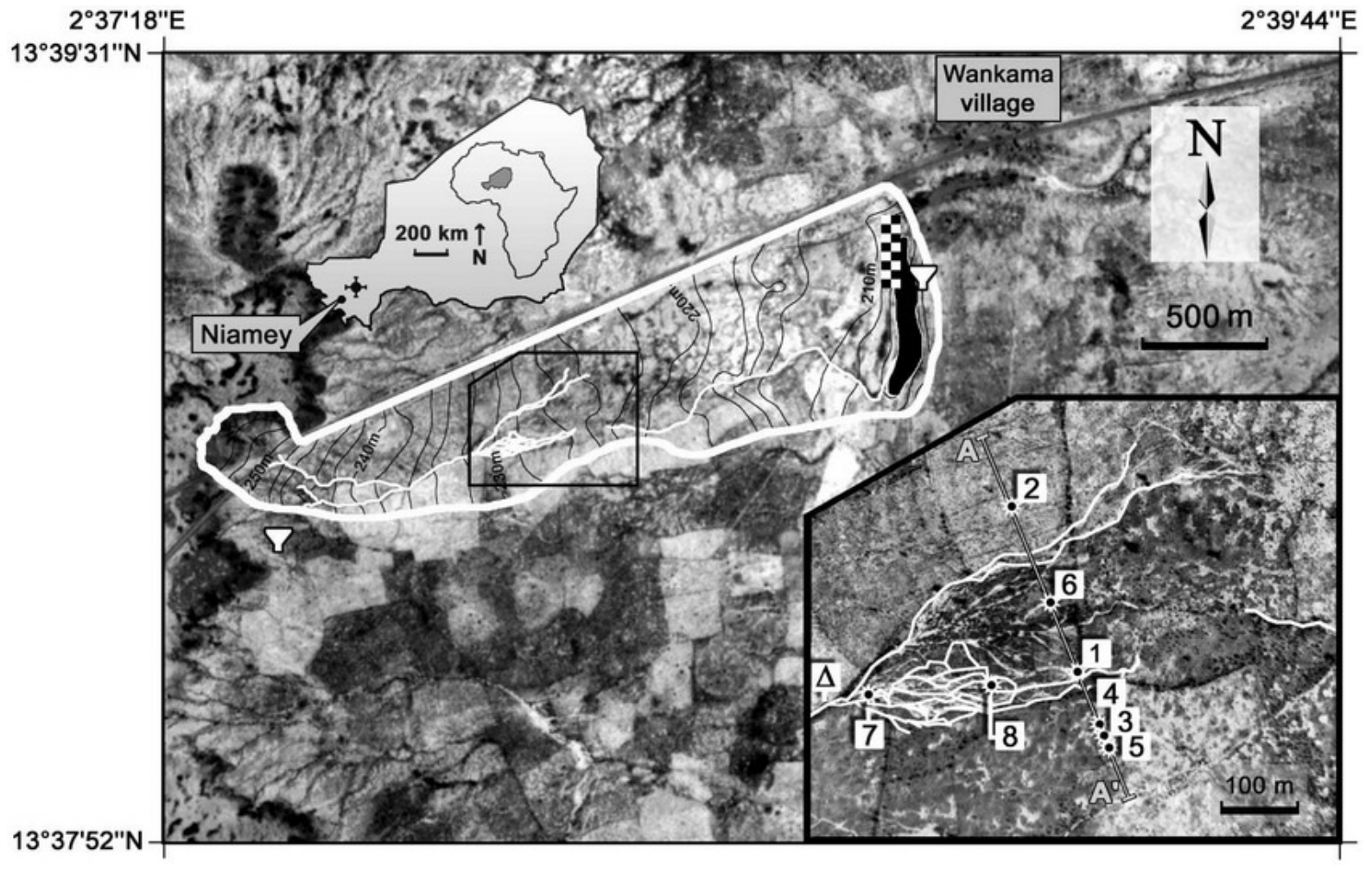

Figure 1 


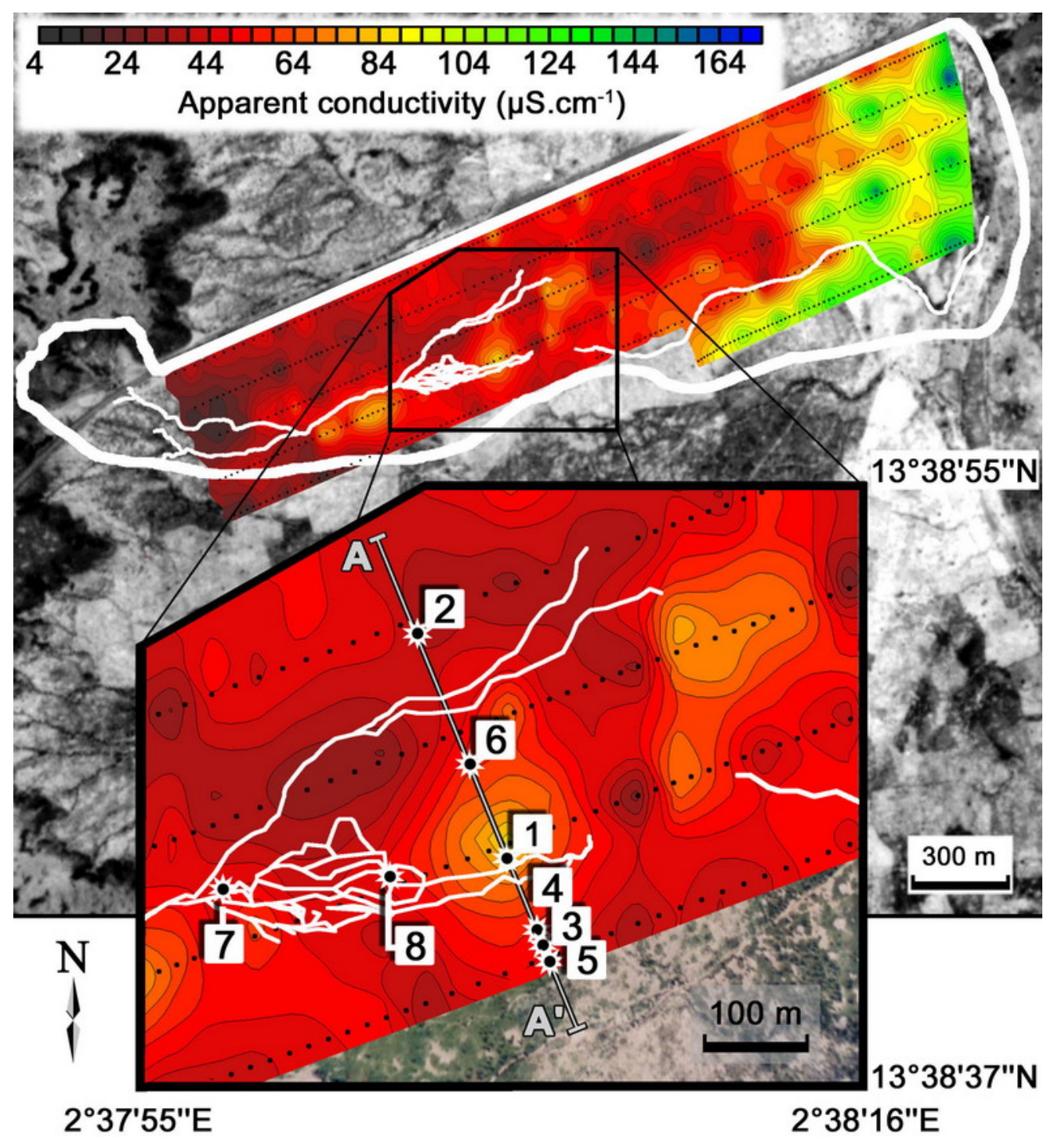

Figure 2 


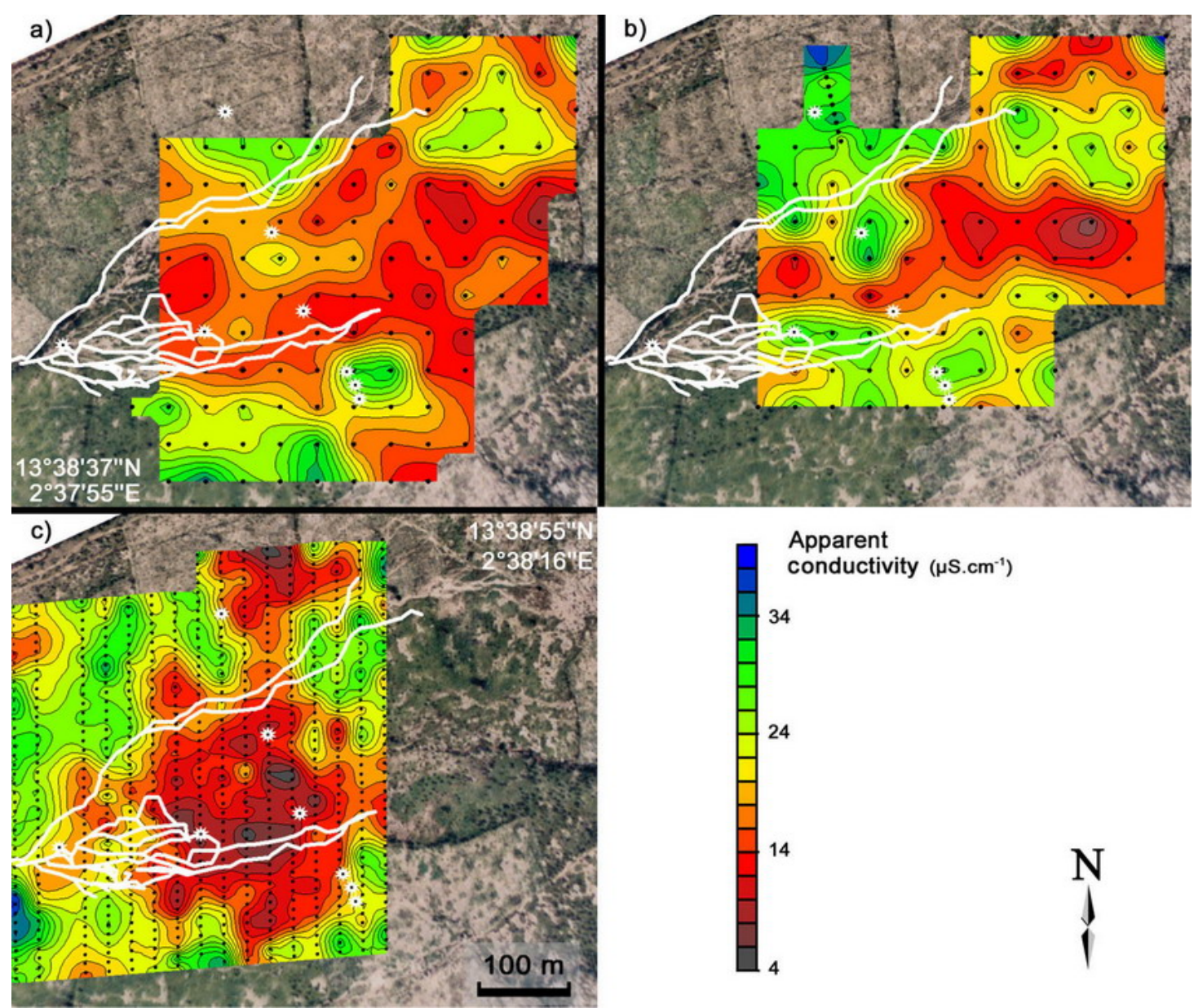

Figure 3 


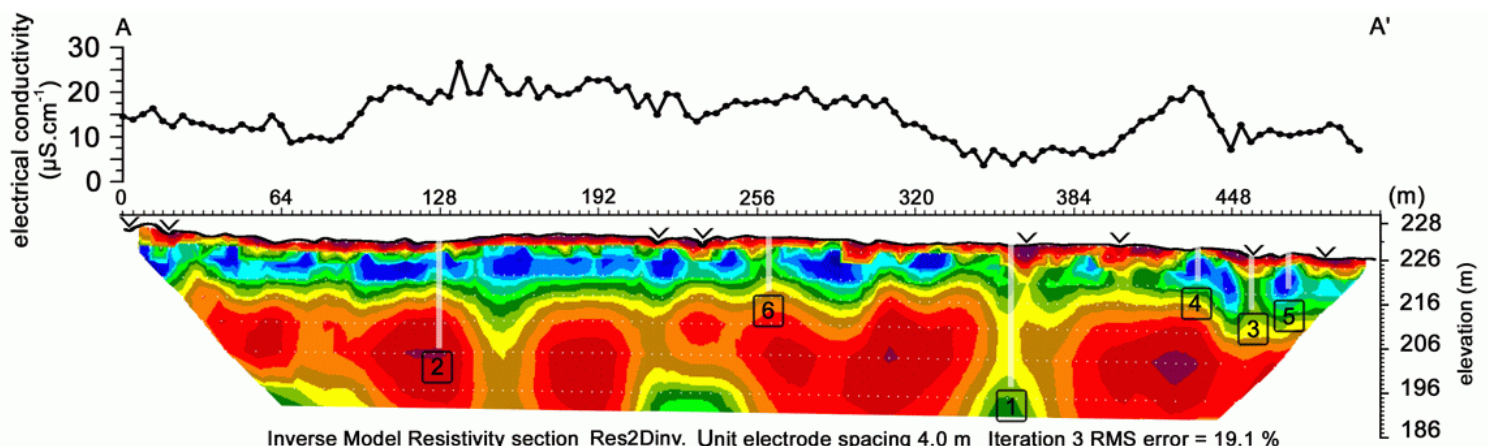

$\checkmark$ sandy channels

\begin{tabular}{|c|c|c|c|c|c|c|c|c|}
\hline 341 & 156 & 72 & 33 & 15 & 6.9 & 3.2 & 1.4 & conductivity in $\mu S . \mathrm{cm}^{-1}$ \\
\hline 29.3 & 63.9 & 139 & 304 & 664 & 144 & 3163 & 6904 & resistivity in ohm.m \\
\hline
\end{tabular}

Figure 4 


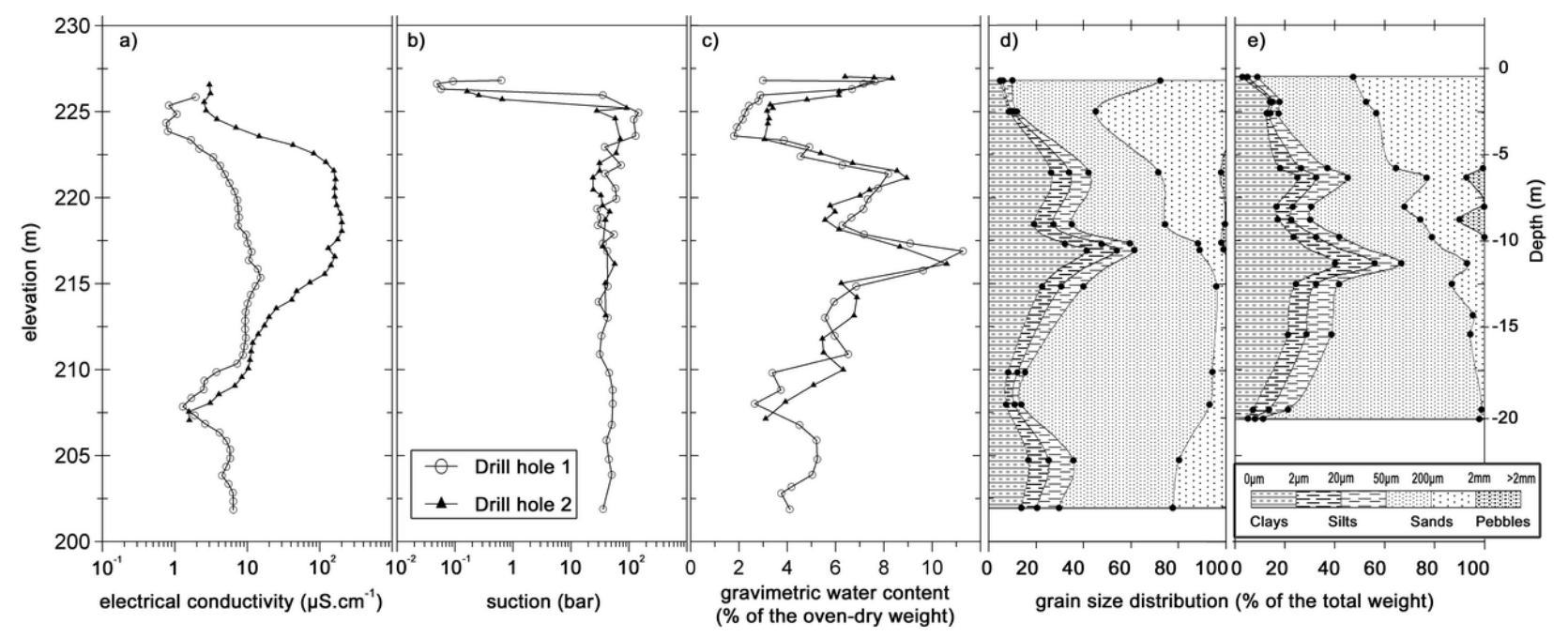

Figure 5 


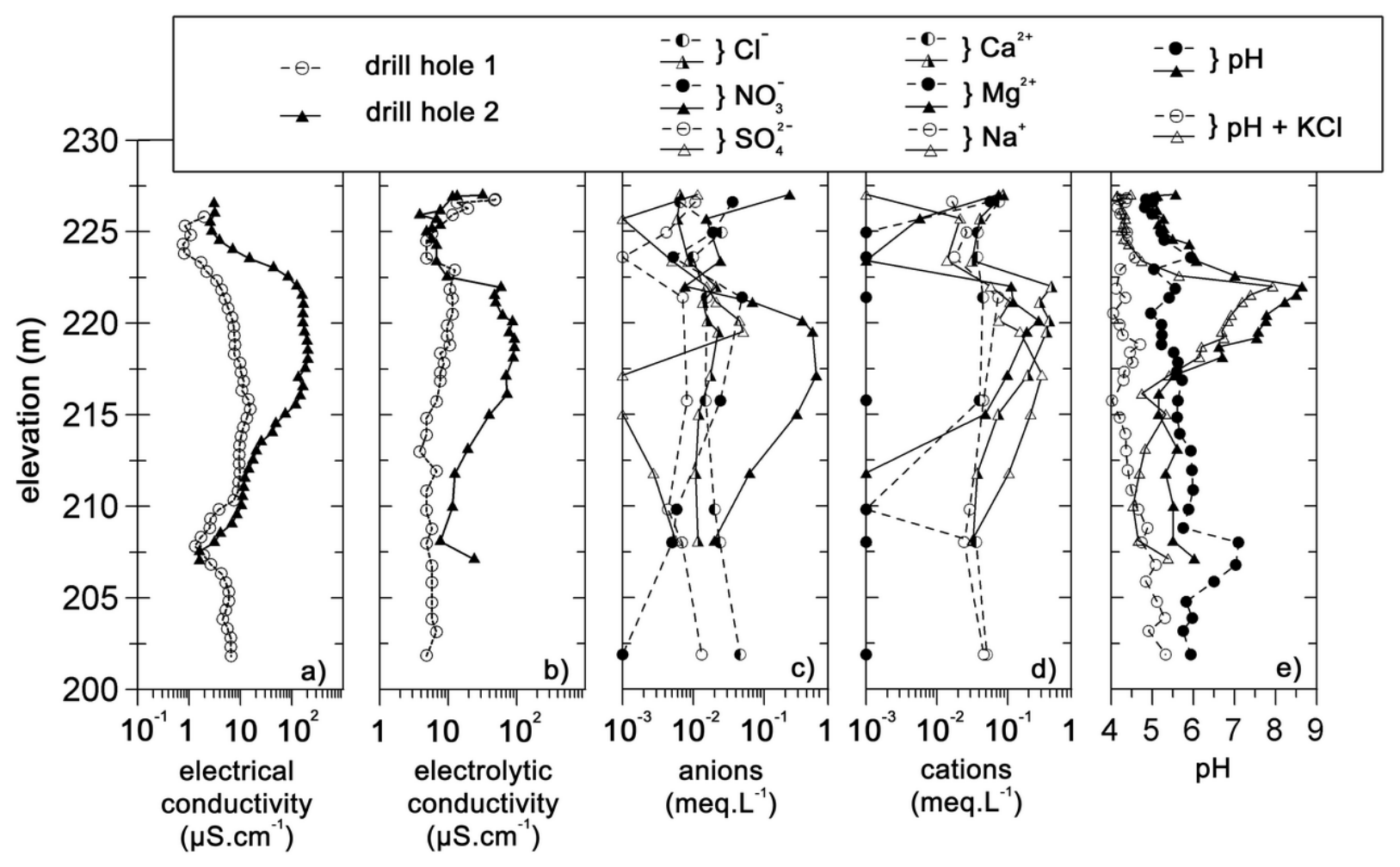

Figure 6 

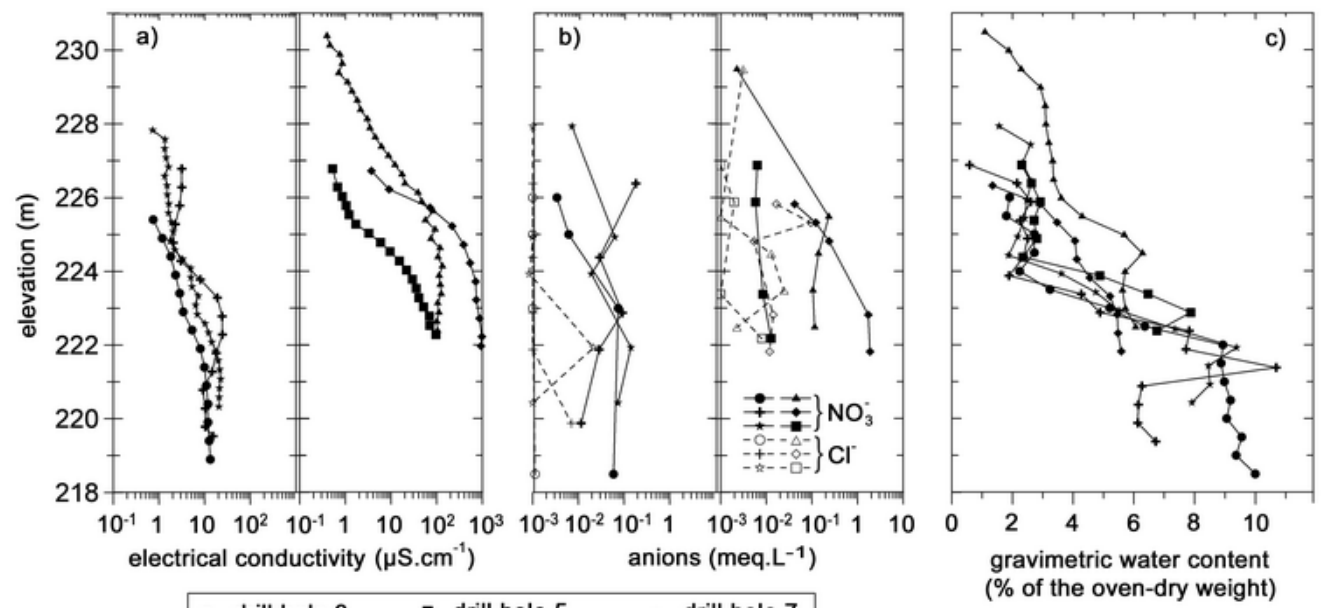

\begin{tabular}{|lll|}
\hline - drill hole 3 & - drill hole 5 & औ drill hole 7 \\
- drill hole 4 & + drill hole 6 & * drill hole 8
\end{tabular}
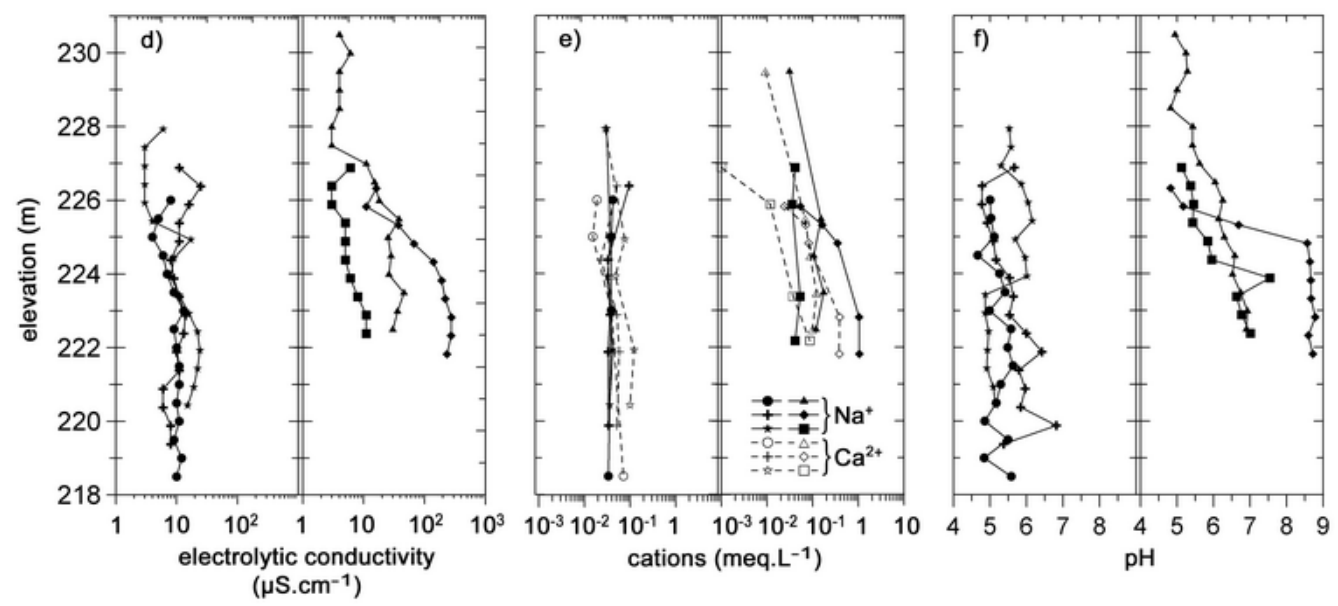

Figure 7 


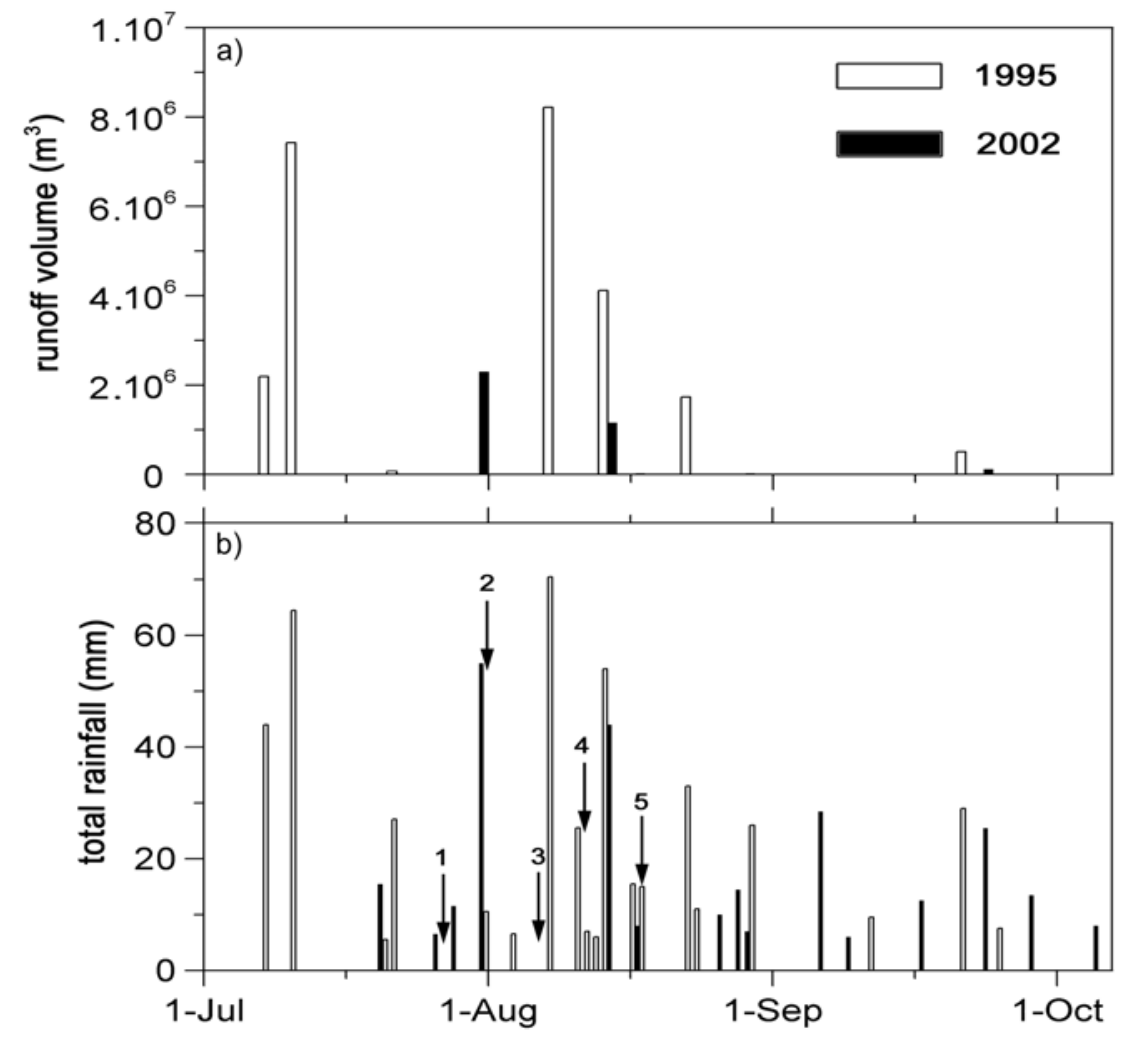

Figure 8 


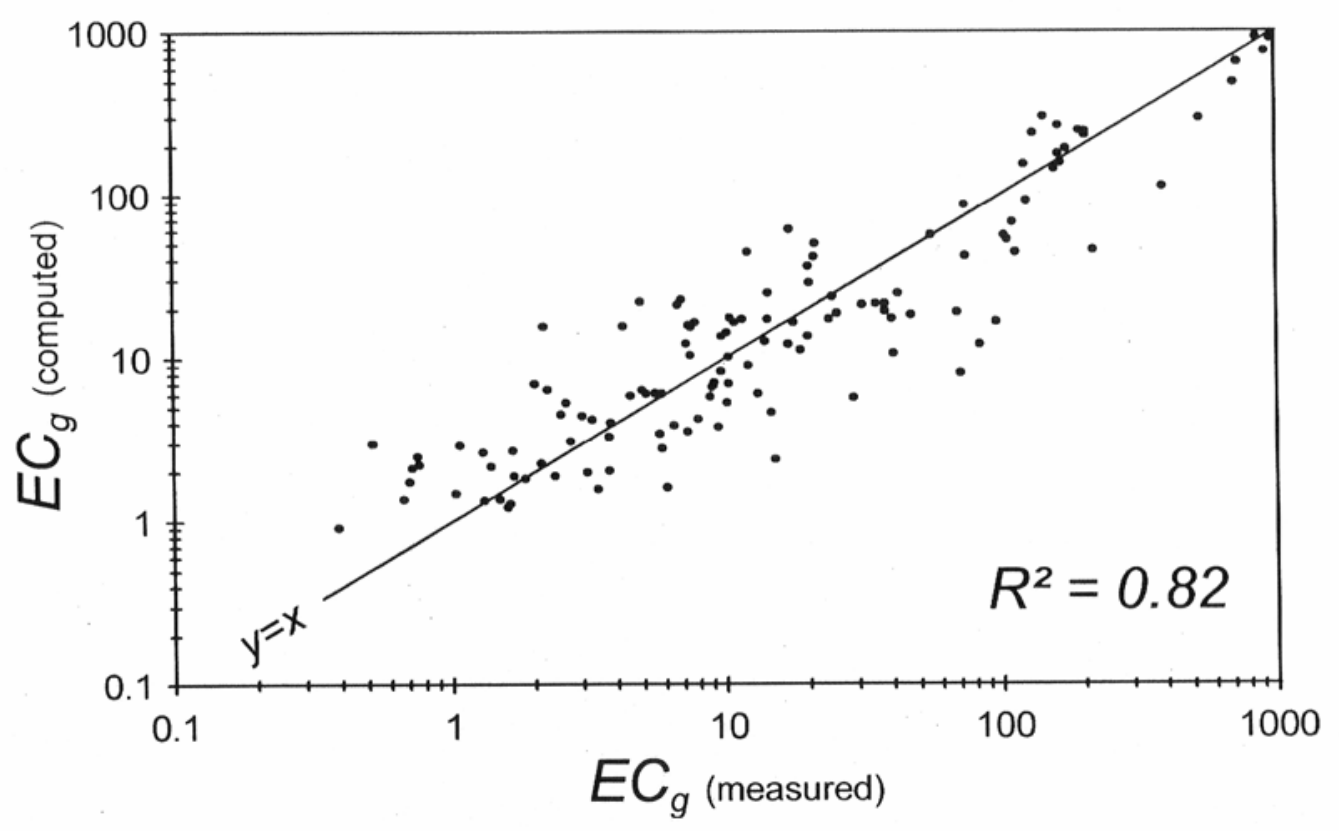

Figure 9 